\title{
Income Inequality and Transnational Corporate Penetration
}

\author{
by \\ Linda Beer \\ Emory University \\ email: lbeer@e.emory.edu
}

Cite: Beer, Linda. (1999). "Income Inequality and Transnational Corporate

Penetration." Journal of World-Systems Research http://jwsr.ucr.edu/ 5: 1-25.

C 1999 Linda Beer.

[Page 1]

Journal of World-Systems Research

\begin{abstract}
This study examines whether the positive association between national income inequality and transnational corporate penetration found previously by Bornschier and Chase-Dunn (1985) and others circa the late 1960s still holds for the mid-1980s. Both methodological and theoretical problems of earlier studies are discussed and solutions are offered. Economic development, political-institutional and regional variables are also included in the analyses. While further research is warranted, the results provide support for a WorldSystem/Dependency perspective in understanding income inequality cross -nationally.

\section{INTRODUCTION}

Bornschier and Chase-Dunn's seminal 1985 work, Transnational Corporations and Underdevelopment, provided a revitalized foundation for quantitative crossnational research on income inequality from a World-System/Dependency perspective. The authors focused on the relationship between transnational corporate penetration and underdevelopment as a primary mechanism of capitalist exploitation and maintenance of the core/periphery hierarchy in the world economy. Foreign economic involvement by transnational corporations (TNCs) in the economies of less-developed countries (LDCs) was argued to be one means by which powerful world actors maintain an inherently unequal global division of labor. Using linear regression techniques on an improved cross-national data set, Bornschier and Chase-Dunn (1985) presented empirical tests of their hypotheses, which confirmed a positive relationship between levels of foreign corporate penetration and income inequality.
\end{abstract}


With one important exception (Tsai 1995), most recent work on cross-national income inequality has moved away from the examination of the impact of foreign direct investment (FDI) dependence on income distribution, focusing instead, for example, on the effects of economic and socio-cultural dualism (Williamson 1991; Nielsen and Alderson 1995) or technoecological heritage (Lenski and Nolan 1985; Crenshaw and Ameen 1994). This is surprising because foreign direct investment has dramatically increased in importance over the past two decades and is currently the primary source of resource flows to developing nations (Froot 1993; Tsai 1995). Indeed, LDCs are encouraged to attract foreign investment as one route to economic growth and well-being in the contemporary world-economy. Foreign investment is promoted by development professionals and lending agencies such as the World Bank as an efficient way to add to existing domestic pools of capital, technology and entrepreneurial talent (Rothgeb 1996).

Specification of the relationship between FDI and income distribution in LDCs is far from complete. Further examination of the processes specified by WorldSystem/Dependency researchers is necessary, and it is especially crucial to examine the effect of FDI over the past two decades. This study takes the important step of quantitatively examining the relationship between TNC penetration and income inequality during the mid-1980's. The majority of previous studies have used data from the late-1960's and early-1970's and calls for more contemporary analyses are frequent (Krahn and Gartrell 1985; Ragin and Bradshaw 1992). In addition, while most previous studies indicate that high levels of foreign control over the economies of LDCs are associated with income inequality during the 1960s and 1970s, Tsai (1996) found th at, with the specification of geographical region, the effects of foreign penetration were marginal. This is a significant contribution to the body of literature on the subject, and the following study will address this critique by incorporating regional variables into the analyses.

[Page 2]

Journal of World-Systems Research

Many researchers have examined recent changes in the world economy, but quantitative studies have largely ignored the possible impact of these changes on the relationship between transnational corporate penetration and income inequality. As Gereffi (1989) and others have argued, the declining significance of industrialization in national economies has implications for development theory. In addition, the rise of certain newly industrialized countries has affected traditional global spacioeconomic hierarchies (Haggard 1990).

Recent improvements in data accessibility and quality allow us to more reliably test World-System/Dependency arguments concerning the deleterious effect of TNC penetration on income distribution. The analyses presented here also incorporate the insights of various researchers into the study of national income inequality. The data are an improvement over most previous studies; indicators are available for a greater number 
of nations and comparability issues have been addressed. Additionally, the correctly specified economic development variables and regional indicators are included in the equations, in order to ensure that the empirical results are not spurious. Moreover, I use the percentage of income accruing to the top $10 \%$ as one of the two inequality indicators in the models, which is unprecedented by previous literature on the subject. Theoretically, this is a better test of World-System/Dependency theories, as these arguments focus on the concentration of income for the elite segments of national populations.

The research presented in the following sections is a first step in the process of incorporating temporal change into our understanding of the structural processes of crossnational inequality; its limited aim is an updated empirical test of the WorldSystem/Dependency model. After an overview of the theoretical model, I briefly discuss the variables used and related methodological issues. Then, the updated Born schier and Chase-Dunn regression model is analyzed. Following this, additional politicalinstitutional variables, which some have argued that Dependency research has ignored (i.e. Muller 1988), will be added to the equations for a more rigorous test of the model. This will also serve to further specify the redistributive effects of national government structure on income inequality, as well as provide a more complete picture of the processes affecting the relationship between TNC penetration and national we lfare. In the final section, I present a discussion of the results of the study, as well as my conclusions regarding directions for future research on this topic.

\section{THEORETICAL PERSPECTIVES}

\section{Modernization/Developmental Theories of Income Inequality}

Modernization or developmental theories of income distribution predict that developing nations will exhibit higher levels of income inequality relative to both non-industrial and industrialized countries. However, these scholars argue that, as economic growth continues, income distribution within these nations becomes more equitable. This approach is most frequently associated with the work of Simon Kuznets $(1955,1963$, 1976) who found a curvlinear association between income inequality and economic growth, and was among the first to develop a theoretical argument to explain this finding.

[Page 3]

Journal of World-Systems Research

Modernization theorists argue that wealth concentrates in the hands of a few entrepreneurs in the early stages of industrialization, as this is the most efficient use of scarce capital (Crenshaw and Ameen 1994). Increasing the rate of capital investment, both foreign and domestic, depends on the development of modern economic segments of the economy. This process entails the expropriation of surplus capital from other segments, and is hardest on the extractive and agricultural economic sectors. At this early 
stage of industrialization, the state plays a critical role in social capital accumulation by implementing policies which ease the burden on these sectors as their surplus is transferred to modern industries in urban areas (Rostow 1960).

The link between economic growth and income inequality from a Modernization/Developmental perspective is the notion of spacial disparities in growth. These theorists argue that industrialization creates uneven development among sectors of the national economy. As urban modern industries grow, individuals involved in these sectors become relatively advantaged compared to other portions of the population, especially those in rural traditional industries such as agriculture. This creates disparities not only in income, but in social welfare, political power and integration into markets. Therefore, economic growth leads to economic dualism and high levels of inc ome inequality among national populations; the mechanism which links industrialization and income distribution is sectoral and spacial disparities in the distribution of wealth.

As national development and urbanization continue over time, Modernization the orists hypothesize that income inequality decreases. Capital concentration becomes less urgent in the latter stages of industrialization, as urbanization economies are realized and modern economic activities and institutions diffuse from urban to rural areas. The process of spacial disarticulation found in early stages of development gives way to spacial integration in the later stages.

Theorists in this tradition argue that continued economic growth expands the middle class and increases employment and saving rates among the poor, leading to decreasing income disparity ( Paukert 1973; Cheney and Syrquin 1975; Ahluwalia 1976; Kuznets 1976). This approach asserts that industrialization eventually expands employment opportunities for the entire population, generates occupational specialization which increases the bargaining power of labor and improves quality of life by decreasing the cost of living (Deane 1979). In addition, economic growth provides incentives for selfinterested elites to voluntarily divest portions of their wealth to the population in order to increase consumption by creating mass markets for their goods, decrease conflict and legitimate the power structure (Lenski 1966).

New research in this tradition seeks to explain the Kuznet's "inverted-U" by reference to a comprehensive dualistic explanation which sees aspects of development as transitional. Nielsen (1994) and Nielsen and Alderson $(1995 ; 1997)$ argue that the curvlinear relationship between income inequality and development is due to "transitional development processes related to the dualism (both economic and generalized) of traditional and modern sectors of developing societies." (Nielsen 1994). Sector dualism, and hence the high levels of income inequality which are brought about by such processes, are a temporary consequence of the labor force shifts and wage differentials between, and within, traditional agrarian and modern industrial sectors of developing societies. Inequality is also an unintended consequence of the demographic trans ition and resultant generalized dualism, which includes the uneven diffusion of sociocultural traits associated with earning power, such as education. It is not development per se, but 
dualism and diffusion processes which are argued to be the keys to expl aining income inequality (Nielsen and Alderson 1995).

[Page 4]

Journal of World-Systems Research

The empirical evidence from the literature which tests for the relationship between economic development and income inequality cross -nationally is mixed. While many have found a significant Kuznets-type inverted U-shaped association (Crenshaw and Ameen 1994; Weede 1993, 1989; Crenshaw 1992; Muller 1988; Johnson 1986; Weede and Tiefenbach 1981), others have found development to be insignificant when other variables are included in their models (Nielsen 1994; Simpson 1990; Chan 1989; Muller 1989; Prechel 1985; Stack 1980). More recent studies have failed to confirm the Kuznet hypothesis using improved longitudinal data (Deninger and Squire 1997, 1996), timeseries analyses (Sasaki et al 1997), or examination of case studies (Bowman 1997). Clearly, further empirical work is needed in this area. While the present study is primarily focused on examining the effect of transnational corporate penetration on national income distribution, the statistical models will include a curvlinear specification of economic development. In addition to subjecting the Kuznet's "inverted-U" hypothesis to further examination, this will also ensure that the findings concerning the effects of FDI dependence on inequality are not spurious.

\section{World-System/Dependency Theories of Income Inequality}

As opposed to Modernization theory's emphasis on the internal dynamics of economic growth, World-System and Dependency theories are neo-Marxist perspectives that focus on the global structure of the capitalist world economy. Most completely elaborated in the work of Wallerstein $(1974,1979,1989)$ and Cardoso and Faletto $(1979)$, among others, this approach argues that national economic growth, inequality and sociopolitical change can only be understood through the analysis of a nation's relative position in the spacioeconomic hierarchy of the world system. That is, the relationship between economic growth and income inequality within any single nation is dependent on that society's relational position in the world division of labor and global power structure. It is asserted that the dynamics of capitalist accumulation in developing countries are different than the processes observable in core nations (Prechel 1985). The issue that WorldSystem/Dependency analyses point our attention to is not the lack of economic growth in developing nations, but the type of growth their dependent status affords them and it's consequences.

In the World-System/Dependency pers pective, capitalist development is dependent on social and material inequality and this inequality is in turn a result of incorporation into the world system. National economic growth and income distribution are in large part determined by growth potentials of productive activities in the larger global structure. Therefore, this approach hypothesizes that stratification of income will correspond with 
the world division of labor and position in the world economy. This is a difficult concept to operationalize and, while some researchers have found that position within the spacioeconomic hierarchy affects inequality independent of other factors (Nolan 1983; Bornschier and Chase-Dunn 1985), most recent studies have found insignificant effects when this concept is operationalized as core/periphery dummy variables included in cross-national regression models (Muller 1988; Simpson 1990; Crenshaw 1992). Although not fully settled in the literature, the relationship between spacio-economic position and inequality is in all probability more complex than can be captured by dichotomous variables, and other researchers have argued that core/periphery status is likely to work indirectly toward increasing inequality through the mechanisins discussed below (Simpson 1990).

There are variants to the World-System/Dependency approach regarding the creation of income inequality, some of which emphasize concentration of land ownership (Furtado 1970; Muller and Seligsen 1987; Boswell and Dixon 1990) or national export-structure (Baran 1957; Frank 1967; Galtung 1971; Prechel 1985). The following study focuses on the effect of cross-national capital transfers, which some have argued are more indicative of dependency status during the past twenty to thirty years than are trade-based measures (Prechel 1985; Chan 1989). This strand of the literature emphasizes foreign direct investment as the primary means through which the modern capitalist world-system creates, and maintains, intra- and international socioeconomic inequities. Many empirical studies of this relationship have confirmed a significant association between foreign corporate penetration (an indicator of the amount of foreign ownership and control over a host economy) and inequality (Evans and Timberlake 1980; Kohli et al 1984; Bo rnschier and Chase-Dunn 1985; Chan 1989; London and Robinson 1989; Crenshaw and Ameen 1994; Dixon and Boswell 1996). Other studies find this association only in certain geographical regions (Rothgeb 1993; Tsai 1995). Even those scholars which fail to confirm this relationship generally report their conclusions with reservation and do not dismiss TNC penetration as a potentially important determinant of income inequality (Weede and Tiefenbach 1981; Crenshaw 1992).

[Page 5]

Journal of World-Systems Research

In the World-System/Dependency perspective there are three mechanisms that are hypothesized to link foreign investment and social inequality (Crenshaw and Ameen 1994). First, foreign investment in developing countries generates large sectoral disparities in the national economy, creates labor aristocracies and results in the underutilization of indigenous labor. Second, transnational corporations operating in developing nations accrue a disproportionate share of local sources of credit and repatriate profits rather than reinvesting them in the local economy. Finally, the governments of these nations, motivated by the necessity (generated by their incorporation into the capitalist world economy) of attracting and maintaining foreign investment, implement policies and strategies that decrease the power of labor and inhibit 
vertical mobility. These include tax concessions, guarantees of profit repatriation, and labor laws unfavorable to workers (London and Robinson 1989).

Scholars in the World-System/Dependency tradition argue that the relationship between foreign investment and internal income inequality has different effects on various sectors of the economy, but in all segments it creates and sustains income inequality in the national population (Crenshaw and Ameen 1994). Foreign capital investment in the agricultural sector destroys traditional production processes and leads to unemployment and overurbanization through its capital intensive means of organization (i.e. labor shedding, land enclosure). In the extractive sector of the economy, foreign investment benefits only a small portion of the national population and thereby increases income inequality. This is because TNC penetration in this sector creates only a small well-paid labor force and because owne rship of natural resources is typically concentrated.

World-System theorists argue that foreign investment in the manufacturing sector has the most harmful effect on national income distribution. National economies in non-core nations with large manufacturing sectors have high levels of income inequality because profits in this sector are increased by the maintenance of a large, surplus low-wage labor force. Therefore, high rates of income inequality are in the interest of transnational corporations and national elites who benefit from foreign investment; they have little incentive to take action to distribute income more equitably. Contrary to the hypotheses of Modernization theorists, the World-System perspective argues that the uneven development of highly penetrated developing economies benefits transnational corporations in that the only segment of the population which can afford to buy these manufactured goods is the wealthy elite (Evans and Timberlake 1980; Prechel 1985; London and Robinson 1989). Domestic demand for these goods depends on the concentration of wealth and high levels of income inequality. Although redistribution of wealth and the resultant expansion of markets may be in the long term interest of foreign corporations, they are driven primarily by the short-term profit logic of capitalism (Bornschier and Chase-Dunn 1985).

Furthermore, there is a convergence of interests between transnational corporations and the wealthy elite segments of the national population in maintaining income inequality which creates barriers to the "trickle-down" effect of industrialization predicted by Modernization theories. In addition to the incentives for inequity for foreign investors discussed above, the national elite strive to maintain their power and higher income so as to maintain privileged consumption patterns and access to status symbols. A common international class interest in the persistence of high levels of inequality thus link foreign investors and indigenous elites, leading these powerful groups to support (and in some cases attempt to increase) the existing unequal income distribution and to coopt and repress opposition from other segments of the population (Bornschier, Chase-Dunn and Rubinson 1977; Bornschier and Ballmer-Cao 1979; Nolan 1983; Bornschier and ChaseDunn 1985; Stokes and Anderson 1990).

[Page 6]

Joumal of World-Systems Research 
World-System/Dependency theories take issue with the Modernization argument that all capital investment is beneficial, distinguishing between the consequen ces of different forms of investment (Dixon and Boswell 1996). Moreover, they reject the hypothesis that the benefits of development to national elites inevitably "trickle-down" to the larger population, emphasizing how intranational class interests and structural barriers impact the possibilities for improvements in social welfare. This approach directs our attention to the connections between countries, and how these links structure the potentials for growth and well-being in discrete nations. In addition, the approach addresses microfoundations by showing, for example, how income inequality benefits the shortterm interests of powerful actors within developing nations.

\section{DATA AND MEASURES}

\section{The Measurement of Income Inequality}

Many researchers have recognized problems with cross-national measures of income inequality (e.g. Ahluwalia 1993[1974]; Muller 1993[1984]). As Hoover (1989: 1008) notes in his work assessing the comparability of various types of income inequality data, most cross-national studies of this phenomena have been "relatively insensitive to issues of data quality and comparability." Fortunately, data collection procedures have improved in recent years, and much work has been done in assessing the strengths and weaknesses of various measures of income inequality, as well as their collection and interpretation.

Ahluwalia (1993[1974]) notes that income inequality is a difficult concept to measure quantitatively and is frequently incorrectly specified. The two most commonly used measures of income inequality are the Gini coefficient, which looks at the disparity between equal and actual distribution of income among quintile shares, and the proportion of income received by the top $20 \%$ of the population ${ }^{1}$. Use of the Gini coefficient has been extensively critiqued on both methodological as well as theoretical fronts (Braun 1991; Hoover 1989; Chan 1989; Muller 1993[1984]).

It is, however, generally for theoretical reasons that many researchers opt to use shares of income instead of the Gini coefficient. Muller (1993[1984]) argues that percentile shares of income are the most appropriate measures because World-System/Dependency arguments point to the concentration of income in the upper end of the distribution as the crucial indicator of income inequality. The Gini score is a measure of the variation of quintile scores from an equal distribution. As there is little variation in the bottom $20 \%$, the difference between concentration in the top percentiles and the Gini score is due almost entirely to the distribution in the middle. In addition, the use of upper proportional shares of income has been argued to indirectly measure asset inequality, another significant dimension of economic stratification (Boswell and Dixon 1993). Considering these theoretical concerns, I will use both the top $10 \%$ and top $20 \%$ percentage shares of total income to measure income inequality. Moreover, as stated in the introduction, the 
use of top decile shares of income is unprecedented in previous literature and is a better test of World-System/Dependency arguments.

The measurement of fractile shares of income as an indicator of income inequality also presents methodological problems, most importantly regarding the reliability and comparability of the data. One of these issues concerns the temporal ordering of variables. Cross-national data on percentage share of income is usually not available for a substantial number of countries for a short time span, for example over two or three years. Frequently, data on income inequality in cross-national studies covers an extended period of time, often temporally preceding the independent variables. As income distribution is a relatively stable structural characteristic most researchers agree that the variable can be validly included even where the measures temporally precede the independent variables to some degree (Chan 1989; Nielsen 1994). While income inequality does change, this change is usually relatively slow. That is, income distribution measures typically exhibit only small changes from year to year.

[Page 7]

Journal of World-Systems Research

Scholars have debated the appropriate length of the time span, however, with some arguing for five year (Muller 1993[1984]), nine year (Hoover 1989), or eleven year (Chan 1989) time periods. This issue is important because, as Hoover (1989) indicates, while income distribution is relatively stable, we cannot uncritically assume that factors influencing its variability operate in the same way at all points in time. Other scholars have argued that the need for a larger sample justifies the use of a wider time period, and have found the same empirical patterns using different time restrictions (Chan 1989). For this reason, I limit the measurement of the income inequality variable to a 14 year period (1979-1993). This decision is based on the need for a larger sample, as well as the fact that this work examines the Dependency model in the mid $-80 \mathrm{~s}^{2}$. With this time restriction there is no overlap with Bornschier and Chase-Dunn (1985), and little with past Dependency studies.

Another issue in the measurement of income inequality concerns the comparability of the data, which researchers often collect from various sources in order to increase sample size. This can lead to problems if, for example, the data is not national in coverage or is based on different income-receiving units or income concepts (Hoover 1989).

Fortunately, since income data collection has improved in recent years, I obtained the data used in this study from a single source, the 1995 World Bank Development Report (WBDR). The WBDR has been cited as the best available source of income data and has less comparability problems than other data sets, although standardized data collection procedures have not yet been established in all countries (Hoover 1989; Muller (1993[1984]). 
Hence, this data set improves upon those used in previous cross-national research on income inequality in three ways. First, the data is updated and derived from one of the most recent sources available ${ }^{\underline{3}}$. Use of this dataset in the present study is an important first step in updating the modeling of national income distribution beyond the late-1960's and early-1970's data used in the majority of previous studies (important exceptions are Johnson 1986 and Nielsen and Alderson 1995). As stated previo usly, this update will allow us to determine if the relationships specified in the late 1960 s were still operating in the mid-1980s. In addition, I take theoretical concerns into account by using percentile shares of income rather than the Gini coefficient, since the testing of WorldSystem/Dependency arguments directs our focus on the distribution of income in the upper portions of the population. Furthermore, the use of top $10 \%$ shares of income is more relevant to these concerns as it indicates greater concentration, and the use of this measure is rare in previous studies of this topic. Finally, I have addressed methodological issues by using data from a limited time frame and from a single source to insure that validity and comparability problems are minimized.

\section{Measurement of the Independent Variables}

Following the full Dependency model specified by Bornschier and Chase-Dunn (1985), I use five independent variables in the linear regression equations predicting income inequality in models \#1-\#4 (Table 1) and \#8-\#11 (Table 2). Logged real GDP per capita in 1985 (RGDPPCLN) (from Summers and Heston's 1995 PENN World Table Mark 5.6 data set) is included to control for level of economic development. This measure is an improvement over those studies, including Bornschier and Chase-Dunn's, which use logged GNP per capita without purchasing power parities. In a correct specification of the development/inequality relationship, logged real GDP per capita squared (RGDPPC2) is also included in the model, as level of economic development and income inequality are hypothesized by Modernization/Developmental theorists to exhibit a cross -sectional curvlinear association (Kuznets 1955, 1963, 1976).

[Page 8]

Journal of World-Systems Research

The measurement of transnational corporate penetration (PEN) is the ratio between foreign direct investment inward stock (from the World Investment Report 1996) and market GDP (from the World Tables 1995) in 1985. As a measure of foreign control over the host economy, this variable is both a methodological and theoretical improvement over those used previously (Dixon and Boswell 1996). One measure of the effect of state socioeconomic and sociopolitical processes, a dummy-coded variable of communist government in 1985 (COM) is included in the model. The coding of this variable is based on The World in Figures: Editorial Information Compiled by The Economist (1987). This operationalization is not the same as that used by Bornschier and Chase-Dunn (1985). However, it is primarily included in their study as a control variable. Both variables measure the same underlying concept and address the argument that Muller (1993[1984]) 
and others have made, which states that the redistributive effects of government mitigate the relationship between income inequality and other variables. In addition, I created a core country dummy-coded variable (CORE) as a measure of position in the spacioeconomic hierarchy in $1985^{4}$. However, this variable was not included in the equations separately because it in itself has no substantive meaning net of the economic development and capital dependency measures. Rather, an interaction term between CORE and PEN(CORE*PEN) was included in the model to control for the possible negative association between core position and income inequality. It is this measure that is the theoretically relevant test of World-System/Dependency arguments because it captures the different processes at work in the core relative to developing nations.

Political-institutional variables are added to the regression equations in models \#5-7 and \#12-\#14, to more rigorously test the Dependency model specified by Bornschier and Chase-Dunn. As World-System/Dependency theorists argue that both position within the world economy - as well as sociopolitical processes - have an impact on levels of state economic inequality, further specification of these relationships is warranted. In addition, the effects of national state structures on income inequality is a subject of contentious debate in the literature. The results of studies examining the relationship between democracy and inequality are inconclusive and contradictory (Hughes 1997). Many studies find no causal relation between the two (Bollen and Jackman 1985; Weede 1989, 1993), while others find a negative association (Stack 1980; Muller 1988, 1995; Nielsen 1994). Still other researchers conclude that democracy has a net positive effect on income inequality (Simpson 1990; Crenshaw 1992). Clearly, this process needs further specification.

For this reason, I include two additional dummy variables in the regression models. The first is an indicator of democratic regime, derived from Gurr's Polity III data set. This variable was constructed by creating an average democracy score for each nation for the period 1980 to 1985 . The distribution of the data revealed a clear threshold point which distinguished democratic regimes from non-democratic ones, an average democracy score of 6.66 or higher. Therefore, for ease of interpretation, a dummy variable was constructed (DEM) from these average democracy index scores. The second is a variable indicating social democratic representation in parliament (SOCDEM). Some researchers have found positive effects of social democratic parties on income distribution (Hewitt 1977; Huber, Ragin and Stephens 1993), but most cross-national studies have not included regime type systematically. Separating the effects of social democratic versus non-social democratic government may explain the contradictory findings surrounding the effects of democracy discussed above. Many studies have found the cooperative public-private structures that characterize social democratic regimes promote overall social welfare, increasing national economic security and equality (Hicks 1988; Kenworthy 1995). The social democratic government indicator is dummy coded 1 for majority participation in parliament between 1980 and 1985, based on information obtained from The Statesman's Yearbook (1987).

[Page 9]

Joumal of World-Systems Research 


\section{ANALYSIS AND RESULTS}

Table 1 presents the OLS regression models of the relationship between the top decile income share measure of income inequality and the independent variables for countries with populations over one million in 1985 . I will discuss these equations first, and then contrast the results with those of the models predicting top quintile income shares (Table 2). No outliers were found for any of the regression analyses and a full list of all nations included in the models is included in Appendix A. Following the Dependency model presented by Bornschier and Chase-Dunn (1985), the measures were entered into the equation one at a time in models \#1-4 in order to examine the theoretically specified effects of the independent variables. State government variables are introduced into the equation in models \#5-7.

[Page 10]

Joumal of World-Systems Research

Table 1

Regression of Income Percentage Share (1985)

Top $10 \%$ :

\section{Equations}

\begin{tabular}{|c|c|c|c|c|c|c|c|}
\hline Predictor: & (1) & (2) & (3) & (4) & (5) & (6) & (7) \\
\hline RGDPPCLN & $\begin{array}{l}37.91 * * * \\
(13.6)\end{array}$ & $\begin{array}{l}32.50 \% * * \\
(13.06)\end{array}$ & $\begin{array}{l}37.66 * * * \\
(13.29)\end{array}$ & $\begin{array}{l}29.76 * * \\
(16.79)\end{array}$ & $\begin{array}{l}32.40 \% * * \\
(13.31)\end{array}$ & $\begin{array}{l}27.74 * * \\
(13.07)\end{array}$ & $\begin{array}{l}33.05 * * * \\
(13.16)\end{array}$ \\
\hline RGDPPCLN2 & $\begin{array}{l}-2.56 \% * \% \\
(.84)\end{array}$ & $\begin{array}{l}-2.23 * * * \\
(.81)\end{array}$ & $\begin{array}{l}-2.55 \% * * \\
(.82)\end{array}$ & $\begin{array}{l}-2.01 * * \\
(1.08)\end{array}$ & $\begin{array}{l}-2.23 * * * \\
(.83)\end{array}$ & $\begin{array}{l}-1.88 * * \\
(.82)\end{array}$ & $\begin{array}{l}-2.20 \% * * \\
(.82)\end{array}$ \\
\hline PEN & --- & $\begin{array}{l}1.88 \% * * \\
(.58)\end{array}$ & $\begin{array}{l}1.36 * * \\
.66)\end{array}$ & $\begin{array}{l}1.45 * * \\
(.72)\end{array}$ & $\begin{array}{l}1.88 \% * * \\
(.58)\end{array}$ & $\begin{array}{l}1.92 \% * * \\
(.57)\end{array}$ & $\begin{array}{l}1.35 * * \\
. .64)\end{array}$ \\
\hline $\mathrm{COM}$ & --- & --- & $\begin{array}{l}-7.42 \% \\
(4.66)\end{array}$ & $\begin{array}{l}-7.31 * \\
(4.82)\end{array}$ & --- & --- & $\begin{array}{l}-8.22 * * \\
(4.56)\end{array}$ \\
\hline CORE & --- & --- & --- & $\begin{array}{l}-4.81 \\
(7.19)\end{array}$ & --- & --- & --- \\
\hline CORE*PEN & --- & --- & --- & $\begin{array}{l}-.65 \\
(1.92)\end{array}$ & --- & --- & --- \\
\hline DEM & --- & --- & --- & --- & $\begin{array}{l}-.114 \\
(2.36)\end{array}$ & --- & --- \\
\hline SOCDEM & --- & --- & --- & --- & --- & $-4.59 * *$ & $-4.98 * *$ \\
\hline
\end{tabular}




$\begin{array}{llllllll} & & & & & & (2.5) & (2.47) \\ \text { CONSTANT } & -105.19 * * * & -76.64 * & -98.7 * & -69.66 * * & -76.35 * & -60.44 & -83.5 * \\ & (54.13) & (52.32) & (53.49) & (65.39) & (53.09) & (52.09) & (2.47) \\ \text { F } & 11.55^{* * *} & 11.8 * * * & 9.71 * * * & 6.43 * * * & 8.7 * * * & 10.03 * * * & 8.98 * * * \\ \text { Adj. R2 } & .24 & .34 & .35 & .34 & .33 & .36 & .38 \\ \text { N } & 68 & 65 & 65 & 65 & 65 & 65 & 65 \\ 1 \text { tailed significance levels: } & & & & & \\ * * *-p<.01, * *-p<.05, *-p<.10 & & & & \end{array}$

[Page 11]

Journal of World-Systems Research

Table 1, equation 1 indicates that income share percentages do indeed exhibit a curvlinear relationship with logged real GDP per capita. That is, income inequality is greater where the national economy is at middle levels of development. This indicates support for the "level of development" paradigm, most commonly associated with Simon Kuznets and the "inverted U" curve (Kuznets 1955, 1963, 1976), but is also consistent with the WorldSystem prediction of higher income inequality in the semi-periphery.

The World-System/Dependency paradigm is tested by bringing the transnational corporate penetration (PEN), communist government (COM), and interaction term between core status and PEN (CORE*PEN) variables into the regression equations (equations 2, 3 and 4). The relationship between PEN and TOP10 is, as expected, positive and significant, even when controlling for other factors. The communist government variable has a significant and negative relationship with TOP10. That is, nations with communist governments have relatively less income inequality than non-communist states. The positive association between TOP10 and PEN is stable with the inclusion of other variables and provides strong support for the World-System/Dependency contention that nations whose economies are highly penetrated by foreign corporations exhibit greater degrees of income inequality. The inclusion of the TNC penetration measure increases the variance explained by the equations from .24 to .34 . However, contrary to the findings of Bornschier and Chase-Dunn for the late 1960 's, the interaction term between the core and penetration measures is not significant, nor does it offer any additional explanatory power to the equation. I discuss the potential explanations for, and implications of, the disparate empirical findings of this study and that of Bornschier and Chase-Dunn in the conclusion.

Moving to the equations which include the additional political-institutional variables (\#57), we see that economic development continues to exhibit a curvlinear association with inequality. Importantly, PEN remains significant with the addition of increased specification of government type; the positive association between high transnational corporate penetration and top decile income percentage share seems to be robust. Democratic status appears to have an insignificant effect on income distribution. Both 
COM and SOCDEM are significantly negatively associated with TOP10; these forms of government have less income inequality relative to non-communist non-democracies and liberal democracies. Together with the development and penetration measures, these variables explain $38 \%$ of the variance in top decile income shares (\#7).

[Page 12]

Journal of World-Systems Research

\section{Table 2}

Regression of Income Percentage Share (1985)

Top 20\%:

Equations

\begin{tabular}{|c|c|c|c|c|c|c|c|}
\hline Predictor: & (8) & (9) & (10) & (11) & (12) & (13) & (14) \\
\hline RGDPPCLN & $\begin{array}{l}42.11 * * * \\
(14.39)\end{array}$ & $\begin{array}{l}36.68 * * * \\
(13.75)\end{array}$ & $\begin{array}{l}41.98 \% * * \\
(13.96)\end{array}$ & $\begin{array}{l}33.60 * * \\
(17.75)\end{array}$ & $\begin{array}{l}37.43 * * * \\
(13.95)\end{array}$ & $\begin{array}{l}31.49 * * \\
(13.80)\end{array}$ & $\begin{array}{l}36.89 \% * \% \\
(13.87)\end{array}$ \\
\hline RGDPPCLN2 & $\begin{array}{l}-2.80 * * * \\
(.89)\end{array}$ & $\begin{array}{l}-2.48 * * * \\
(.85)\end{array}$ & $\begin{array}{l}-2.80 * * * \\
(.87)\end{array}$ & $\begin{array}{l}-2.23 * * \\
(1.14)\end{array}$ & $\begin{array}{l}-2.54 * * * \\
(.87)\end{array}$ & $\begin{array}{l}-2.10^{* * *} \\
(.86)\end{array}$ & $\begin{array}{l}-2.42 * * * \\
(.87)\end{array}$ \\
\hline PEN & --- & $\begin{array}{l}1.99 * * * \\
(.61)\end{array}$ & $\begin{array}{l}1.44 * * \\
(.69)\end{array}$ & $\begin{array}{l}1.52 * * \\
(.76)\end{array}$ & $\begin{array}{l}1.98 * * * \\
(.62)\end{array}$ & $\begin{array}{l}2.04 * * * \\
(.60)\end{array}$ & $\begin{array}{l}1.44 * * \\
(.68)\end{array}$ \\
\hline COM & --- & --- & $\begin{array}{l}-7.97^{*} \\
(4.92)\end{array}$ & $\begin{array}{l}-7.91 \% \\
(5.09)\end{array}$ & --- & --- & $\begin{array}{l}-8.75^{* *} \\
(4.82)\end{array}$ \\
\hline CORE & --- & --- & --- & $\begin{array}{l}-4.76 \\
(7.63)\end{array}$ & --- & --- & --- \\
\hline CORE*PEN & --- & --- & --- & $\begin{array}{l}-.56 \\
(2.03)\end{array}$ & --- & --- & --- \\
\hline DEM & --- & --- & --- & --- & $\begin{array}{l}1.05 \\
(2.45)\end{array}$ & --- & --- \\
\hline SOCDEM & --- & --- & --- & --- & --- & $\begin{array}{l}-4.82 * * \\
(2.65)\end{array}$ & $\begin{array}{l}-5.20 * * \\
(2.61)\end{array}$ \\
\hline CONSTANT & $\begin{array}{l}-107.25 * * \\
(57.26)\end{array}$ & $\begin{array}{r}-78.29^{*} \\
(55.09)\end{array}$ & $\begin{array}{c}-101.01 \% * \\
(56.16)\end{array}$ & $\begin{array}{l}-70.24 \\
(69.08)\end{array}$ & $\begin{array}{c}-80.39 * \\
(55.68)\end{array}$ & $\begin{array}{r}-60.46 \\
(54.98)\end{array}$ & $\begin{array}{l}-83.98 * \\
(55.51)\end{array}$ \\
\hline$r$ & $10.01 * * *$ & $10.72 * * *$ & $8.90 * * *$ & $5.90 * * *$ & $5.46 * * *$ & $9.16^{* * *}$ & $8.26 * * *$ \\
\hline Adj. R2 & .21 & .31 & .32 & .31 & .30 & .33 & .36 \\
\hline $\mathrm{V}$ & 69 & 66 & 66 & 66 & 66 & 66 & 66 \\
\hline
\end{tabular}

1 tailed significance levels:

$* * *-p<.01, * *-p<.05, *-p<.10$

[Page 13]

Joumal of World-Systems Research 
Turning to the models predicting top quintile income share (Table 2), we see that the results are similar to those predicting decile share. The economic development variables continue to exhibit a significant curvelinear association with income inequality. As in the models predicting TOP10, the communist government variable has a positive relationship with TOP20 and the CORE*PEN interaction term is insignificant. The robust and positive PEN effect found in the models predicting decile income share are replicated in these models as well, as are the effects of government type. I present a discussion of these results and explore their implications for the study of cross-national income inequality in the next section.

[Page 14]

Journal of World-Systems Research

Table 3

Regression of Income Percentage Share (1985)

Equations

\begin{tabular}{|c|c|c|}
\hline Predictor: & $\begin{array}{l}\text { TOP10 } \\
\text { (15) }\end{array}$ & $\begin{array}{l}\text { TOP20: } \\
\text { (16) }\end{array}$ \\
\hline RGDPPCLN & $\begin{array}{l}13.05 \\
(13.83)\end{array}$ & $\begin{array}{l}17.41 \\
(14.51)\end{array}$ \\
\hline RGDPPCLN2 & $\begin{array}{l}-.94 \\
(.86\end{array}$ & $\begin{array}{c}-1.19^{*} \\
(.91)\end{array}$ \\
\hline PEN & $\begin{array}{l}1.32 \% * \\
(.61)\end{array}$ & $\begin{array}{l}1.41 * * \\
(.66)\end{array}$ \\
\hline $\mathrm{COM}$ & $\begin{array}{c}-5.62 * \\
(4.30)\end{array}$ & $\begin{array}{l}-6.09^{*} \\
(4.58)\end{array}$ \\
\hline SOCDEM & $\begin{array}{l}-5.48^{* *} \\
(2.31)\end{array}$ & $\begin{array}{r}-5.86^{* *} \\
(2.45)\end{array}$ \\
\hline ASIA & $\begin{array}{c}-1.22 \\
(2.61)\end{array}$ & $\begin{array}{l}-1.72 \\
(2.77)\end{array}$ \\
\hline LA & $\begin{array}{l}7.14 * * * \\
(2.21)\end{array}$ & $\begin{array}{l}7.24 * * * \\
(2.34)\end{array}$ \\
\hline CONSTANT & $\begin{array}{l}-7.02 \\
(54.67)\end{array}$ & $\begin{array}{l}-9.63 \\
(57.34)\end{array}$ \\
\hline $\mathrm{F}$ & $9.45^{* * *}$ & $8.70^{* * *}$ \\
\hline Adj. R2 & .48 & .45 \\
\hline $\mathrm{N}$ & 65 & 66 \\
\hline
\end{tabular}

[Page 15]

Journal of World-Systems Research 
As alluded to previously, Tsai (1995) argues that previous findings of a positive relationship between foreign corporate penetration and income inequality may well be the result of geographical differences in inequality. The empirical models of that study indicated that the effects of FDI were insignificant when regional variables were included in the regression equations. In order to explore this possibility for the present analysis, I introduce regional dummy variables into the core regression equations in Table 3. Following Tsai (1995), I include a Latin American and an East/Southeast Asian indicator in the models predicting TOP10 (\#15) and TOP20 $(\# 16)^{\frac{5}{}}$. The addition of regional specification substantially increases the amount of variance explained, from .38 (\#7) to .48 (\#15) for the equation predicting top decile share and from .36 (\#14) to .45 (\#16) for the equation predicting top quintile share. The development indicators become insignificant, no doubt reflecting systematic differences in regional economic development which are captured by the geographic measures. The leftist politicalinstitutional variables continue to be negatively related to top decile and quintile income share. The results also indicate that Latin American nations have substantially greater income inequality than their counterparts in the reference group. Importantly, however, the FDI penetration measure remains significant and continues to exhibit a positive association with inequality. This indicates that, while the inclusion of regional indicators may be crucial for a full specification of any model predicting income inequality, foreign corporate penetration has an independent delete rious effect on national income distribution, at least for the mid- $80 \mathrm{~s}^{\underline{6}}$.

\section{DISCUSSION AND CONCLUSIONS}

The empirical findings of this study concerning the relationship between transnational corporate penetration and income inequality provide continued support for the WorldSystem/Dependency model, although they are somewhat different than research focusing on an earlier time period. In accordance with the theoretical argument, foreign economic penetration is a significant and robust predictor of the concentration of income in the upper portion of the population. The empirical analyses reveal the "negative externalities" of capital dependency for national income distribution (Dixon and Boswell 1996). These results hold even where other relevant variables, such as level of development or regional specification, are included in the models. Perhaps the greatest contribution of this study is that it takes advantage of recent improvements in data collection and availability, allowing for an examination of the effects of FDI dependence on inequality during a more recent time period than the majority of previous research.

However, the results are not unequivocal. The insignificance of the core/penetration interaction term raises interesting questions for future research. Central to the WorldSystem/Dependency approach is the notion that development processes are different in developing nations (the periphery) relative to industrialized ones (the core). Various explanations can be offered; empirically testing the issues raised by this study would be a significant contribution to the literature on inequality and dependency. 
TNC penetration was at a low point in the mid-80s, which might explain the instability of the penetration effect (Miner 1997). Also, global inequality has increased since the 1965 , especially during the 1980's (Ram 1992; Korzeniewicz and Moran 1997). An examination of changes in penetration and inequality over time should be und ertaken in order to explore this possibility ${ }^{7}$. Alternately, it may be that core nations are becoming increasingly subject to the same negative externalities of foreign penetration that have previously been found for less developed countries. That this might have changed between 1967 and 1985 would not be surprising. Deindustrialization and globalization arguments assert that changes in the structure of the world economy have resulted in the increasing convergence between the core and the periphery in terms of capital mobility (for example, Gereffi 1989). Researchers have noted an increase in income inequality in many core nations during recent decades, especially in the United States (Bluestone and Harrison 1988; Braun 1991; Nielsen 1994). Increasingly, many researchers have focused their attention on the economic and social consequences of relatively recent developments in industrial production and the structure of global capital, focusing on their implications for the core (i.e. Bowles et al 1984; Piore and Sabel 1984; Ross and Trachte 1990). The rise of some of the newly industrialized economies, especially in Southeast Asia where income inequality is relatively low, is further indication of the changes in the relations of global capitalism that have taken place since 1967 (for example, Haggard 1990).

[Page 16]

Journal of World-Systems Research

In conclusion, the positive effect of transnational corporate penetration on income inequality is still supported by the empirical evidence. Even accounting for national regime type, foreign penetration is associated with a greater concentration of income in the top fractiles of the population. The quantitative examination of cross-national income inequality during the past two decades is long overdue. The present research represents an necessary first step toward this end. However, this study raises more issues than it settles. The results leave many question unanswered, especially with re gard to changes in the structure of exploitation and dependence in the world economy. Bornschier and Chase-Dunn (1985) provided evidence of the change in dependence from trade to capital investment relations. The research presented here indicates another change in this process, although the models do not empirically test this hypothesis. I suggest that the explanation might be found in an examination of recent historical developments fluctuations in foreign capital penetration, mediation in core/periphery relations, variation in the mechanisms of capitalist exploitation, the changing nature of effective industrial production, changes in migration patterns - developments which have influenced the relationship between income inequality and transnational corporate penetration, perhaps altering but not eradicating the positive association between the two.

Furthermore, the inclusion of additional political-institutional variables into the equations is an important contribution toward fully specifying the relationship between form of 
government and income inequality. While liberal democratic status had no significant effect on income distribution, social democracies and communist governments exhibited lower shares accruing to both the top $10 \%$ and top $20 \%$ of the population. These results are somewhat intuitive; leftist governments with manifest redistributive ideologies and policies decrease income inequality within their national boundaries. This issue needs exploration, as in many nations where communist governmen ts failed and/or their economies opened, income inequality increased as nations became more highly penetrated by foreign capital.

Future studies should more fully address and explain the issues raised by the empirical results of this research. Specifically, changes in the levels of income inequality and transnational corporate penetration should be added to the models to determine the impact of time on these processes. Different measures of income inequality should be compared. Other factors which have been found to affect income inequality should also be included to explore the interactions between variables, as well as to increase the explanatory power of the model. For example, ecological evolutionary theorists point our attention to agrarian population density as an important determinant of income inequality (Crenshaw and Ameen 1994). Additionally, further exploration of the impact of government regime type on income inequality is warranted. Given the increased accessibility and reliability of data, important questions concerning the effect of globalization on dependency processes may now be empirically tested. The research presented here represents an important first step in exploring the effect of temporal change on the relationship between global structures and underdevelopment, providing evidence for the continued utility of World-System/Dependency explanations of these phenomena.

[Page 17]

Journal of World-Systems Research

\section{NOTES}

1. Income levels of the bottom $20 \%$ are rarely used due to lack of variation. Most nations have around $4-5 \%$.

2. Fifteen observations are for years prior to 1985 (ranging from 1979 to 1984 , see Appendix A), but were retained in the equations because of the increase in sample size. Removing these nations from the analysis results in a loss of variation which leads to increased standard errors, thereby decreasing $\mathrm{t}$-scores. While the associations between the variables remain the same as in the models examining the full data set, the significance of these relationships is reduced in the equations examining the reduced data set. It is possible that this is a result of model underspecification, but is unlikely to be an indication that the reported relationships are solely due to influence of those inequality measures temporally preceding the dependent variables. Moreover, a variable measuring 
the year for which the income distribution data was measured was not significant nor found to alter the relationships between the remainder of variables in the model.

3. Recently the World Bank has made available an expanded income inequality data set which includes both Gini and quintile data over time for a large number of nations, paying close attention to measurement and comparability issues (Deininger and Squire 1996). The use of this data in future research seems quite promising, as it allows for an examination of income inequality over time with a minimization of the methodological problems which have plagued previous quantitative inequality research.

4. A list of the nations designated as core countries in the creation of this dummy variable is provided in Appendix A, and is taken from Crenshaw (1992).

5. An indication of regional designation is provided in Appendix A, and follows Tsai (1995).

6. This is not to argue that the effects of FDI might not vary according to geographical region. Tsai (1995) found evidence of a positive penetration effect on inequality for East/Southeast Asia during the 70s. While a full examination of this issue is beyond the scope of the present study, future research should explore this issue.

7. I am currently working on a project concerning this issue.

\section{REFERENCES}

Ahluwalia, Montek S. 1993[1974]. "Income Inequality: Some Dimensions of the Problem" in Development and Underdevelopment: The Political Economy of Inequality eds. Mitchell A. Seligson and John T. Passe-Smith. Lynne Rienner Publishers. pps. 31 39.

------ 1976. "Inequality, Poverty and Development". Journal of Development Economics 3, pps. 307-342.

Amin, Samir. 1976. Unequal Development: An Essay on the Social Formations of Peripheral Capitalism. Monthly Review Press, New York.

Baran, P.. 1957. The Political Economy of Growth. Monthly Review Press, New York.

Bluestone, Barry and Bennett Harrison. 1988. The Deindustrialization of America.

Bornschier, Volker and Christopher Chase-Dunn. 1985. Transnational Corporations and Underdevelopment. Praeger Publishers.

Bornschier, Volker and Ballmer-Cao, T.H.. 1979. "Income Inequality: A Cross-National Study of the Relationships Between MNC-Penetration, Dimensions of the Power Structure and Income Distribution." American Sociological Review 44, pps. 438-506. 
Bornschier, Volker, Chase-Dunn, Christopher and Rubinson, Richard. 1977. "CrossNational Evidence of the Effects of Foreign Investment and Aid on Economic Growth and Inequality: A Survey of Findings and a Reanalysis." American Journal of Sociology 84, pps. 487-506.

Bollen, Kenneth A. and Robert W. Jackman. 1985. "Political Democracy and the Size Distribution of Income." American Sociological Review46, pps. 651-659.

Boswell, Terry and William J. Dixon. 1993. "Marx's Theory of Rebellion: A CrossNational Analysis of Class Exploitation, Economic Development, and Violent Revolt." American Sociological Review 58, October, pps. 681-702.

------ 1990. "Dependency and Rebellion: A Cross-National Analysis." American Sociological Review 55, pps.540-549.

Bowles, Samuel, David M. Gordon and Thomas E. Weisskopf. 1984. Beyond the Waste Land: A Democratic Alternative to Economic Decline. Anchor Press/Doubleday.

Bowman, Kirk S.. 1997. "Should the Kuznets Effect be Relied on to Induce Equalizing Growth: Evidence from Post-1950 Development?" World Development 25, 1 pps. 127 143.

[Page 18]

Journal of World-Systems Research

Braun, Denny. 1991. The Rich Get Richer: The Rise of Income Inequality in the United States and the World. Nelson-Hall Inc.

Cardoso, Fernando H. and Enzo Faletto. 1979. Dependency and Development in Latin America.

Chan, Steve. 1989. "Income Inequality Among LDCs: A Comparative Analysis of Alternative Perspectives." International Studies Quarterly 33, pps. 45-65.

Chenery, H. and Syrquin, M.. 1975. Patterns of Development 1950-1970. Oxford U. Press, London.

Crenshaw, Edward. 1993. "Polity, Economy and Technoecology: Alternative Explanations for Income Inequality." Social Forces 71, 3, March, pps. 807-816.

1992. "Cross-National Determinants of Income Inequality: A Replication and Extension Using Ecological-Evolutionary Theory." Social Forces 71, pps. 339-363. 
Crenshaw, Edward and Ansari Ameen. 1994. "The Distribution of Income Across National Populations: Testing Multiple Paradigms." Social Science Research 23, 1 , March, pps. 1-22.

Deane, P.. 1979. The First Industrial Revolution. Cambridge U. Press, London.

Deininger, Klaus and Lyn Squire. 1997. "Economic Growth and Income Inequality: Reexamining the Links." Finance and Development, March.

------ 1996. "A New Data Set Measuring Income Inequality." The World Bank Economic Review 10, 3 pps. 565-591.

Dixon, William J. and Terry Boswell. 1996. "Dependency, Disarticulation and Denominator Effects: Another Look at Foreign Capital Penetration." American Journal of Sociology 102, 2 pps. 543-562.

Evans, Peter B. and Michael Timberlake. 1980. "Dependence, Inequality, and the Growth of the Tertiary: A Comparative Analysis of Less Developed Countries." American Sociological Review 45, August, pps. 531-552.

Frank, Andre Gunder. 1967. Capitalism and Development in Latin America. Monthly Review Press, New York.

Froot, Kenneth A. ed.. 1993. Foreign Direct Investment. The University of Chicago Press, Chicago and London.

[Page 19]

Journal of World-Systems Research

Furtado, Celso. 1970. Economic Development of Latin America: Historical Background and Contemporary Problems. Cambridge U. Press, London.

Galtung, J.. 1971. "A Structural Theory of Imperialism"; Journal of Peace Research 8 , 81-117.

Gereffi, Gary. 1989. "Rethinking Development Theory: Insights from East Asia and Latin America." Sociological Forum, 4: 505-533.

Haggard, Stephan. 1990. Pathways From the Periphery: The Polities of Growth in the Newly Industrializing Economies. Cornell University Press.

Hewitt, Christopher. 1977. "The Effect of Political Democracy and Social Democracy on Equality in Industrial Societies: A Cross-National Comparison." American Sociological Review 42, pps. 450-464. 
Hicks, Alexander. 1988. "Social Democratic Corporatism and Economic Growth." Journal of Politics 50,3, August.

Hoover, Greg A. 1989. "Intranational Inequality: A Cross-National Data Set." Social Forces 67, 4, June, pps. 1008-1026.

Huber, Evelyne, Charles Ragin and John Stevens. 1993. "Social Democracy, Christian Democracy, Constitutional Structure and the Welfare State." American Journal of Sociology 99, pps. 711-749.

Hughes, Marion R. 1997. "Sample Selection Bias in Analyses of the Political Democracy and Income Inequality Relationship." Social Forces 75, 3, March, pps, 1101-1117.

Johnson, R. Burke. 1986. "Income Inequality in the Third World: A Comparison of Three Theories." International Review of Modern Sociology 16, pps. 69-81.

Kenworthy, Lane. 1995. In Search of National Economic Success. Thousand Oaks, CA: Sage.

Kohli, Atul and Michael F. Altfeld, Saideh Lotfian, Russell Mardon. 1984. "Inequality in the Third World: An Assessment of Competing Explanations." Comparative Political Studies 17,3, October, pps. 283-318.

Korzeniewicz, Roberto Patricio and Timothy Patrick Moran. 1997. "World Economic Trends in the Distribution of Income, 1965-1992". American Journal of Sociology 102, 4, January, pps. 1000-1039.

[Page 20]

Journal of World-Systems Research

Krahn, Harvey and John W. Gartrell. 1985. "Effects of Foreign Trade, Government Spending, and World-System Status on Income Distribution." Rural Sociology 50, 2, pps. 181-192.

Kuznets, Simon. 1976. Modern Economic Growth: Rate, Structure and Spread. Yale U. Press.

1963. "Quantitative Aspects of the Economic Growth of Nations. VIII: The Distribution of Income by Size." Economic Development and Cultural Change 11, 1-80.

1955. "Economic Growth and Income Inequality." American Economic Review 45 , pps. $1-28$. 
Lecaillon, J. and F. Paukert, C. Morrisson, D. Germidis. 1994. Income Distribution and Economic Development: An Analytical Survey. Geneva, Switzerland: International Labor Office.

Lenski, G.. 1966. Power and Privilege: A Theory of Social Stratification. McGraw-Hill, New York.

Lenski, G. and P. Nolan. 1985. "Technoeconomic Heritage, Patterns of Development, and the Advantage of Backwardness." Social Forces 64, 2, December, pps. 341-358.

London, Bruce and Tom Robinson. 1989. "The Effects of International Dependence on Income Inequality and Political Violence." American Sociological Review 54, April, pps. 305-308.

Miner, Stephen. 1997. "Transnational Corporate Penetration and Economic Development." Master's Thesis, Department of Sociology, Emory University, Atlanta, GA.

Muller, Edward N. 1995. "Economic Determinants of Democracy." American Sociological Review 54, pps. 966-982.

1993[1984]. "Financial Dependence in the Capitalist World Economy and the Distribution of Income Within States." in Development and Underdevelopment: The Political Economy of Inequality eds. Mitchell A. Seligson and John T. Passe-Smith. Lynne Rienner Publishers. pps. 267-293.

1989. "Distribution of Income in Advanced Capitalist States: Political Parties, Labor Unions, and the International Economy." European Journal of Political Research 17, pps. 367-400.

[Page 21]

Journal of World-Systems Research

1988. "Democracy, Economic Development, and Income In equality." American Sociological Review 54, pps. 868-871.

Muller, Edward and Seligson, Mitchell. 1987. "Inequality and Insurgency." American Political Science Review 81, pps. 425-449.

Nielsen, Francois. 1994. "Income Inequality and Industrial Development: Dualism Revisited." American Sociological Review 59, October, pps. 654-677. 
Nielsen Francois and Arthur Alderson. 1997. "The Kuznets Curve and the Great U-Turn: Income Inequality in U.S. Counties, 1970 to 1990." American Sociological Review 62, 1, February, pps. 12-33.

1995. "Income Inequality, Development and Dualism: Results from an Unbalanced Cross-National Panel." American Sociological Review 60, pps. 674-701.

Nolan, Patrick D. 1992. "A Standardized Cross-National Comparison of Incomes." Sociological Quarterly 33, 4, winter, pps. 599-609.

Nolan, Patrick D.. 1983. "Status in the World System, Income Inequality and Economic Growth"; American Journal of Sociology 89, 410-419.

Paukert, Felix.. 1973. "Income Distribution at Different Levels of Development: A Survey of the Evidence". International Labor Review 108, pps. 97-125.

Piore, Michael J. and Charles E. Sabel. 1984. The Second Industrial Divide: Possibilities for Prosperity. Basic Books, Inc. Publishers, New York.

Prechel, H.. 1985. "The Effects of Exports, Public Debt and Development on Income Inequality". International Labor Review 108, pps. 97-125.

Ragin, Charles C. And York W. Bradshaw. 1992. "International Economic Dependence and Human Misery, 1938-1980: A Global Perspective." Sociological Perspectives 35, 2, pps. 217-247.

Ram, Rati. 1992. "Intercountry Inequalities in Income and Basic-Needs Indicators: A Recent Perspective." World Development 20,6, pps. 899-905.

Roberts, B.. 1989. "Urbanization, Migration and Development." Sociological Forum 4, 665-691.

Ross, Robert J. S. and Kent C. Trachte. 1990. Global Capitalism: The New Leviathan. State University of New York Press, Albany.

Rostow, W. W.. 1960. The Stages of Economic Growth: A Non-Communist Manifesto. Cambridge U. Press.

[Page 22]

Journal of World-Systems Research

Rothgeb, John M. Jr.. 1996. Foreign Investment and Political Conflict in Developing Countries. Praeger, London. 
1993. "A Regional Analysis of the Relationship Between Foreign Investment and Political Conflict in Developing Countries." Journal of Political and Military Sociology 21, pps. 219-240.

Simpson, Miles. 1993. "Political Power versus Ecological Evolutionary Forces: What Are the Proximal Sources of Income Distribution?" Social Forces 71, 3, March, pps. 797-806.

1990. "Political Rights and Income Inequality: A Cross-National Test." American Sociological Review 55, pps. 682-693.

Stack, Steven. 1980. "The Political Economy of Income Inequality: A Comparative Analysis." Canadian Journal of Political Science 13, pps. 273-286.

The Statesman's Yearbook. 1987. NY: St. Martins Press.

Stokes, R. and Anderson, A.. 1990. "Disarticulation and Human Welfare in LessDeveloped Countries.". American Sociological Review 55, pps. 63-74.

Todaro, M.. 1969. "A Model of Labor Migration and Urban Development in LessDeveloped Countries." American Economic Review 59, pps. 138-148.

Tsai, Pan-Long. 1995. "Foreign Direct Investment and Income Inequality: Further Evidence." World Development 23, 3, pps. 469-483.

Wallerstein, Immanuel. 1989. The Modern World-System III: The Second Era of Great Expansion of the Capitalist World-Economy 1730-1840s. San Diego: Academic Press.

------ 1979. The Capitalist World-Economy. Cambridge: Cambridge University Press.

----- 1974. The Modern World-System I: Capitalist Agriculture andthe Origins of the European World-Economy in the Sixteenth Century. San Diego, CA: Academic Press, Inc.

Weede, Erich. 1993. "The Impact of Democracy or Repressiveness on the Quality of Life, Income Distribution and Economic Growth Rates." International Sociology 8, pps. 177-195.

[Page 23]

Journal of World-Systems Research

1989. "Democracy and Inequality Reconsidered." American Sociological Review 54, pps. 865-868. 
Weede Erich and Horst Tiefenbach. 1981. "Some Recent Explanations of Income Inequality: An Evaluation and Critique." International Studies Quarterly 25, 2, June, pps. 255-282.

Williamson, Jeffrey G.. 1991. Inequality, Poverty, and History. Basil Blackwell, Cambridge, MA.

The World in Figures: Editorial Information Compiled by The Economist. 1987. London. Hodden and Stoughton.

World Data 1995 (cd rom). 1996. World Bank, New York.

World Investment Report 1996: Investment, Trade and International Policy Arrangements. 1996. U.N. Conference on Trade and Development. United Nations, NY and Geneva.

[Page 24]

Journal of World-Systems Research

\section{APPENDIX A}

\section{Country}

United States*

Canada*

Dominican Republic+

Jamaica+

Mexico+

Guatemala +

Honduras+

Nicaraguat

Costa Ricat

Panama+

Colombiat

Venezuelat

Peru+

Brazil+

Boliviat

Chile+

United Kingdom*

Netherlands*

\section{PEN(In) TOP20 YEAR TOP10 YEAR}

$\begin{array}{lllll}-3.14 & 41.9 & 85 & 25 & 85\end{array}$

$\begin{array}{lllll}-1.78 & 40.2 & 87 & 24.10 & 87\end{array}$

$\begin{array}{lllll}-2.85 & 55.6 & 89 & 39.6 & 89\end{array}$

$\begin{array}{lllll}-1.8 & 48.4 & 90 & 32.6 & 90\end{array}$

$\begin{array}{lllll}-2.01 & 55.9 & 84 & 39.5 & 84\end{array}$

$\begin{array}{lllll}-4.57 & 63 & 89 & 46.6 & 89\end{array}$

$\begin{array}{lllll}-3.12 & 63.5 & 89 & 47.9 & 89\end{array}$

$\begin{array}{lllll}-3.59 & 55.3 & 93 & 39.8 & 93\end{array}$

$\begin{array}{lllll}-1.46 & 50.8 & 89 & 34.1 & 89\end{array}$

$\begin{array}{lllll}-2.25 & 59.8 & 89 & 42.1 & 89\end{array}$

$\begin{array}{lllll}-2.68 & 55.8 & 91 & 39.5 & 91\end{array}$

$\begin{array}{lllll}-3.34 & 49.5 & 89 & 33.2 & 89\end{array}$

$\begin{array}{lllll}-3.01 & 51.4 & 85-86 & 35.4 & 85-86\end{array}$

$\begin{array}{lllll}-2.33 & 67.5 & 89 & 51.3 & 89\end{array}$

$\begin{array}{lllll}-1.99 & 48.2 & 90-91 & 31.7 & 90-91\end{array}$

$\begin{array}{lllll}-2.07 & 60.4 & 92 & 4538 & 92\end{array}$

$\begin{array}{lllll}-2.29 & 44.3 & 88 & 27.8 & 88\end{array}$

$\begin{array}{lllll}-2.13 & 36.9 & 88 & 21.9 & 88\end{array}$




\begin{tabular}{|c|c|c|c|c|c|}
\hline France* & -3.23 & 41.9 & 89 & 26.1 & 89 \\
\hline Switzerland* & -2.78 & 44.6 & 82 & 29.8 & 82 \\
\hline Spain & -3.4 & 36.6 & 88 & 21.8 & 88 \\
\hline West Germany* & -3.36 & 40.3 & 88 & 24.4 & 88 \\
\hline Poland & -5.86 & 36.1 & 89 & 21.6 & 89 \\
\hline Hungary & -9.01 & 34.4 & 89 & 20.8 & 89 \\
\hline Italy* & -3.63 & 41.0 & 86 & 25.3 & 86 \\
\hline Finland* & -4.12 & 37.6 & 81 & 21.7 & 81 \\
\hline Sweden* & -3.41 & 36.9 & 81 & 20.8 & 81 \\
\hline Norway* & -2.28 & 36.7 & 79 & 21.2 & 79 \\
\hline Denmark* & -3.3 & 38.6 & 81 & 22.3 & 81 \\
\hline Senegal & -3.08 & 58.6 & $91-92$ & 42.8 & $91-92$ \\
\hline Mauritania & -3.24 & 46.3 & 88 & 30.2 & $87-88$ \\
\hline Cote d'Ivoire & -2.92 & 44.1 & 88 & 28.5 & 88 \\
\hline Ghana & -2.69 & 44.1 & 88 & 29.0 & $88-89$ \\
\hline Nigeria & -1.85 & 49.0 & 92 & 34.2 & 92 \\
\hline Uganda & -6.78 & 41.9 & $89-90$ & 27.2 & $89-90$ \\
\hline Kenya & -2.95 & 61.8 & 92 & 47.9 & 92 \\
\hline Tanzania & -3.79 & 62.7 & 91 & 46.5 & 91 \\
\hline Rwanda & -2.75 & 38.9 & $83-85$ & 24.6 & $83-85$ \\
\hline Ethiopia & -3.97 & 41.3 & 81 & 27.5 & $81-82$ \\
\hline Zambia & -2.1 & 49.7 & 91 & 34.2 & 91 \\
\hline Zimbabwe & -.58 & 62.3 & $90-91$ & 46.9 & $90-91$ \\
\hline South Africa & -4.47 & 63.3 & 93 & 47.3 & 93 \\
\hline Lesotho & -3.15 & 60.0 & $86-87$ & 43.6 & $86-87$ \\
\hline Botswana & -.94 & 58.9 & $85-86$ & 42.9 & $85-86$ \\
\hline Mauritius & -3.71 & 60.5 & --- & --- & --- \\
\hline Morocco & -3.46 & 46.3 & $90-91$ & 30.5 & $90-91$ \\
\hline Algeria & -3.93 & 46.5 & 88 & 31.7 & 88 \\
\hline Tunisia & -1.86 & 46.3 & 90 & 30.7 & 90 \\
\hline Jordan & -2.56 & 47.7 & 91 & 32.6 & 91 \\
\hline Israel & -3.43 & 39.6 & 79 & 23.5 & 79 \\
\hline China\# & -4.11 & 41.8 & 90 & 24.6 & 90 \\
\hline Korea, Republic of\# & -4.1 & 42.2 & 88 & 27.6 & 88 \\
\hline Japan* & -6.16 & 37.5 & 79 & 22.4 & 79 \\
\hline India & -5.38 & 41.3 & $89-90$ & 27.1 & $89-90$ \\
\hline Pakistan & -3.31 & 39.7 & 91 & 25.2 & 91 \\
\hline Bangladesh & -4.97 & 38.6 & $89-89$ & 24.6 & $88-89$ \\
\hline
\end{tabular}




$\begin{array}{llllll}\text { Sri Lanka } & -2.52 & 39.3 & 90 & 25.2 & 90 \\ \text { Nepal } & -7.24 & 39.5 & 84-85 & 25.0 & 84-85 \\ \text { Thailand\# } & -3.08 & 50.7 & 88 & 35.3 & 88 \\ \text { Malaysia\# } & -1.25 & 53.7 & 89 & 37.9 & 89 \\ \text { Singapore\# } & -.33 & 48.9 & 82-83 & 33.5 & 82-83 \\ \text { Philippines\# } & -3.16 & 47.8 & 88 & 32.1 & 88 \\ \text { Indonesia\# } & -1.01 & 42.3 & 90 & 27.9 & 90 \\ \text { Australia* } & -2.05 & 42.2 & 85 & 25.8 & 85 \\ \text { New Zealand* } & -2.86 & 44.7 & 81 & 28.7 & 81-82 \\ \text { Hong Kong } & -2.41 & 47.0 & 80 & 31.3 & 80 \\ \text { *core (Crenshaw 1992) } & & & & & \\ \text { +Latin America (Tsai 1995) } & & & & \\ \text { \#East/Southeast Asia (Tsai 1995) } & & & & \end{array}$

[Page 25]

Journal of World-Systems Research 